\title{
Boosting Antitumor Response by Costimulatory Strategies Driven to 4-1BB and OX40 T-cell Receptors
}

\author{
Daniele E. Mascarelli, ${ }^{1,2}$ Rhubia S. M. Rosa ${ }^{1,2}$, Jessica M. Toscaro ${ }^{1,3}$, \\ Isadora F. Semionatto ${ }^{1,2}$, Luciana P. Ruas ${ }^{1}$, Carolinne T. Fogagnolo ${ }^{1,4}$, Gabriel C. Lima ${ }^{1,5}$ \\ and Marcio C. Bajgelman 1,2,3*

\begin{abstract}
${ }^{1}$ Brazilian Biosciences National Laboratory (LNBio), Brazilian Center for Research in Energy and Materials (CNPEM), Campinas, Brazil, ${ }^{2}$ Faculty of Pharmaceutical Sciences, University of Campinas, Campinas, Brazil, ${ }^{3}$ Medical School, University of Campinas (UNICAMP), Campinas, Brazil, ${ }^{4}$ Medical School of Ribeirão Preto (FMRP), University of São Paulo, Ribeirão Preto, Brazil, ${ }^{5}$ Pro Rectory of Graduation, University of São Paulo, São Paulo, Brazil
\end{abstract}

\section{OPEN ACCESS}

Edited by:

Rodrigo Nalio Ramos, INSERM U1138 Centre de Recherche des Cordeliers (CRC), France

Reviewed by:

Maximilien Grandclaudon, Dana-Farber Cancer Institute,

United States

Sarantis Korniotis,

INSERM U976 Immunologie, Dermatologie, Oncologie, France

*Correspondence:

Marcio C. Bajgelman marcio.bajgelman@Inbio.cnpem.br

Specialty section: This article was submitted to Molecular Medicine,

a section of the journal Frontiers in Cell and Developmental Biology

Received: 09 April 2021 Accepted: 27 May 2021 Published: 30 June 2021

Citation:

Mascarelli DE, Rosa RSM, Toscaro JM, Semionatto IF, Ruas LP,

Fogagnolo CT, Lima GC and

Bajgelman MC (2021) Boosting Antitumor Response by Costimulatory Strategies Driven to 4-1BB and OX4O

T-cell Receptors. Front. Cell Dev. Biol. 9:692982. doi: 10.3389/fcell.2021.692982
Immunotherapy explores several strategies to enhance the host immune system's ability to detect and eliminate cancer cells. The use of antibodies that block immunological checkpoints, such as anti-programed death 1/programed death 1 ligand and cytotoxic T-lymphocyte-associated protein 4 , is widely recognized to generate a long-lasting antitumor immune response in several types of cancer. Evidence indicates that the elimination of tumors by $T$ cells is the key for tumor control. It is well known that costimulatory and coinhibitory pathways are critical regulators in the activation of $T$ cells. Besides blocking checkpoints inhibitors, the agonistic signaling on costimulatory molecules also plays an important role in T-cell activation and antitumor response. Therefore, molecules driven to costimulatory pathways constitute promising targets in cancer therapy. The costimulation of tumor necrosis factor superfamily receptors on lymphocytes surface may transduce signals that control the survival, proliferation, differentiation, and effector functions of these immune cells. Among the members of the tumor necrosis factor receptor superfamily, there are 4-1BB and OX40. Several clinical studies have been carried out targeting these molecules, with agonist monoclonal antibodies, and preclinical studies exploring their ligands and other experimental approaches. In this review, we discuss functional aspects of 4-1BB and OX40 costimulation, as well as the progress of its application in immunotherapies.

Keywords: immunotherapy, T cell costimulation, TNFR, 4-1BB, OX40, cancer therapy, aptamers, agonistic antibody

\section{INTRODUCTION}

Immunotherapy explores the host immune system to enhance antitumor response. The inhibition of immunological checkpoints, on $\mathrm{T}$ cells, such as anti-programed death 1 (PD-1)/programed death 1 ligand (PD-L1) and cytotoxic T-lymphocyte-associated protein 4 (CTLA-4), has been shown to generate long-lasting antitumor immune responses in cancer therapy. However, this approach is effective in only $30 \%$ of patients because of mechanisms of tumor resistance (Chen and Mellman, 2013; Swart et al., 2016). There are several signaling mechanisms that may drive T-cell phenotype switching the balance between immunotolerance and surveillance. 
The tumor necrosis factor receptor superfamily (TNFRSF) encodes T-cell costimulatory receptors that may regulate survival, proliferation, differentiation, and effector functions of immune cells, being a potential target for immunotherapy (Calderhead et al., 1993; Godfrey et al., 1994; Wilcox et al., 2002; Zhang et al., 2010; Melero et al., 2013).

Early experiments with activated T cells have described the cell surface 4-1BB receptor (Kwon and Weissman, 1989; Schwarz et al., 1993). The 4-1BB receptor, also known as TNFRSF9 or $\mathrm{CD} 137$, is a $24-\mathrm{kDa}$ protein located on chromosome 1 p36 (Pollok et al., 1993; Hurtado et al., 1997), which encodes 255 amino acids harboring 64\% homology to the murine sequence (Alderson et al., 1994; Zhou et al., 1995; Chin et al., 2018). The 4-1BB receptor is expressed on activated $\mathrm{T}$ and $\mathrm{B}$ cells, monocytes, macrophages, dendritic cells (DCs), regulatory $\mathrm{T}$ cells (Tregs), and natural killer (NK) cells (Pollok et al., 1993; Langstein et al., 1998; Melero et al., 1998; Laderach et al., 2002; Kim et al., 2008; Schoenbrunn et al., 2012). The 4-1BB receptor harbors two cytoplasmic domains that can bind to the TNFR-associated factor (TRAF) in $\mathrm{T}$ cells. The mammal TRAF may exhibit conserved C-terminal domains (Bouwmeester et al., 2004; Xu et al., 2004), and CD137 can interact with TRAF1, TRAF2, and TRAF3 (Jang et al., 1998). The interaction between CD137, TRAF1, and TRAF2 activates different signaling cascades such as nuclear factor $\kappa \mathrm{B}(\mathrm{NF}$ $\kappa B)$, MAPK (protein kinase activated by mitogen) (Shuford et al., 1997; Arch and Thompson, 1998; Kim et al., 1998), ERK (kinase regulated by extracellular signal), and JNK (Jun N-terminal kinase) (Rothe et al., 1995; Froelich et al., 1996; Arch and Thompson, 1998; Jang et al., 1998; Saoulli et al., 1998; Cannons et al., 2001; Song et al., 2004; Sabbagh et al., 2008). The activation of the NF- $\kappa B$ pathway upregulates survival genes such as $\mathrm{Bcl}-\mathrm{XL}$ and $\mathrm{Bfl}-1$, downregulates proapoptotic molecules such as BIM, and transmits signals that stimulate cell division (Hockenbery et al., 1990; Lee et al., 2002; Bukczynski et al., 2003). Moreover, the 4-1BB/4-1BB ligand (4-1BBL) signaling triggers biochemical signals that increase $\mathrm{T}_{\mathrm{H}} 1$ cytokines, such as interleukin 6 (IL-6), IL-8, TNF, IL-12, and interferon $\gamma$ (IFN- $\gamma)$; suppress $\mathrm{T}_{\mathrm{H}} 2$ cytokines; potentiate activation, survival, proliferation, and cytotoxicity of $\mathrm{T}$ cells; increase IL-2 production; and provoke the maturation of DCs (Shuford et al., 1997; Kim et al., 1998; Laderach et al., 2002; Lee et al., 2002; Wen et al., 2002; Lippert et al., 2008; Fröhlich et al., 2020).

The expression of 4-1BB may be experimentally induced in human and murine $\mathrm{T}$ cells, using different mitogenic agents such as PMA (phorbol 12-myristate 13-acetate), phytohemagglutinin, anti-CD3, lipopolysaccharide, and IL-1 $\beta$ (Pollok et al., 1995; Zhou et al., 1995; Tan et al., 2000). The receptor interacts with 4-1BBL, on the surface of activated antigen-presenting cells (APCs), B cells, macrophages, and other myeloid-derived cells (Goodwin et al., 1993; Pollok et al., 1994; DeBenedette et al., 1997). The expression of 4-1BBL also was observed in cancer cells (Salih et al., 2000). The 4-1BB costimulation of $\mathrm{T}$ cells does not require additional CD28 signaling when a strong engagement of T-cell receptors (TCRs) occurs, producing high levels of IL2 and enhancing $\mathrm{T}_{\mathrm{H}} 1$ response and cytotoxic $\mathrm{T}$-cell activity
(Shuford et al., 1997; Saoulli et al., 1998; Takahashi et al., 1999; Cannons et al., 2000; Dawicki et al., 2004).

Another T-cell costimulatory receptor that belongs to the TNFRSF family is the OX40 receptor, also known as CD134, TNFRSF4, and ACT35. The OX40 receptor and its ligand (OX40L, TNFSF4, CD252) were first described in mice and harbor 63\% homology to that of human (Paterson et al., 1987; Mallett et al., 1990; Godfrey et al., 1994). The human OX40 gene is located in on chromosome 1p36, encodes 277 amino acids, a 29-kDa protein (Latza et al., 1994).

The OX40 is expressed in activated $\mathrm{CD}^{+}$and $\mathrm{CD}^{+}{ }^{+} \mathrm{T}$ cells, Tregs, T follicular helper cells, NK cells, and neutrophils (Mallett et al., 1990; Godfrey et al., 1994; Melero et al., 1998; Bansal-Pakala et al., 2004; Baumann et al., 2004; Vu et al., 2007; Zaini et al., 2007; Tahiliani et al., 2017). The antigenic stimulation of the TCR by major histocompatibility complex molecules upregulates OX40 expression on the surface of $\mathrm{T}$ cells, which may be potentiated by a CD28-CD80 signaling (Walker et al., 1999; Rogers et al., 2001). The OX40 peak expression is seen from 24 to $72 \mathrm{~h}$ after the TCR activation (Rogers et al., 2001; Song et al., 2008; Sadler et al., 2014). Once expressed, OX40 can bind to OX40L, which is mainly expressed on APCs (Linton et al., 2003; Jenkins et al., 2007; Karulf et al., 2010). The OX40/OX40L interaction triggers a signaling cascade, similar to $4-1 \mathrm{BB} / 4-1 \mathrm{BBL}$, inducing transcriptional changes to modulate the immune response, such as T-cell proliferation and survival. The immunomodulatory functions associated with OX40, such as the PKB pathway, promote the inhibition of cellular apoptosis, as well as increase the signaling by TCR antigenic stimuli (Song et al., 2004). The OX40 stimulation activates NF- $\mathrm{B}$ pathway, which indirectly increases expression of apoptosis-suppressing proteins prolonging cell survival, and the activated T-cell nuclear factor (NFAT) pathway that leads to an increase in the synthesis of cytokines such as IL-2, IL-4, IL-5, and IFN- $\gamma$ (So and Croft, 2007). Although, some data suggest the importance of OX40/OX40L signaling for primary and memory $\mathrm{T}_{\mathrm{H}} 2$ response (Salek-Ardakani et al., 2003; Jenkins et al., 2007; Pattarini et al., 2017), there are also evidences that OX40 costimulation plays an important role in the $\mathrm{T}_{\mathrm{H}} 1$ response (Weinberg et al., 1999; De Smedt et al., 2002; Gajdasik et al., 2020). Therefore, it was observed that OX40 costimulation may enhance both a $\mathrm{T}_{\mathrm{H}} 1$ and a $\mathrm{T}_{\mathrm{H}} 2$ response without supporting the role for switching polarization of $\mathrm{CD} 4^{+}$ T cells (De Smedt et al., 2002).

In this review, functional aspects of $4-1 \mathrm{BB}$ and OX4 will be discussed, as well as the progress of its application in immunotherapies.

\section{COSTIMULATION OF 4-1BB AND OX40 RECEPTORS ENHANCES T-CELL ACTIVITY AND POTENTIATES ANTITUMOR RESPONSE}

Both 4-1BB and OX40 costimulatory signaling on $\mathrm{T}$ cells are reported to boost antitumor immune responses (Figure 1). 


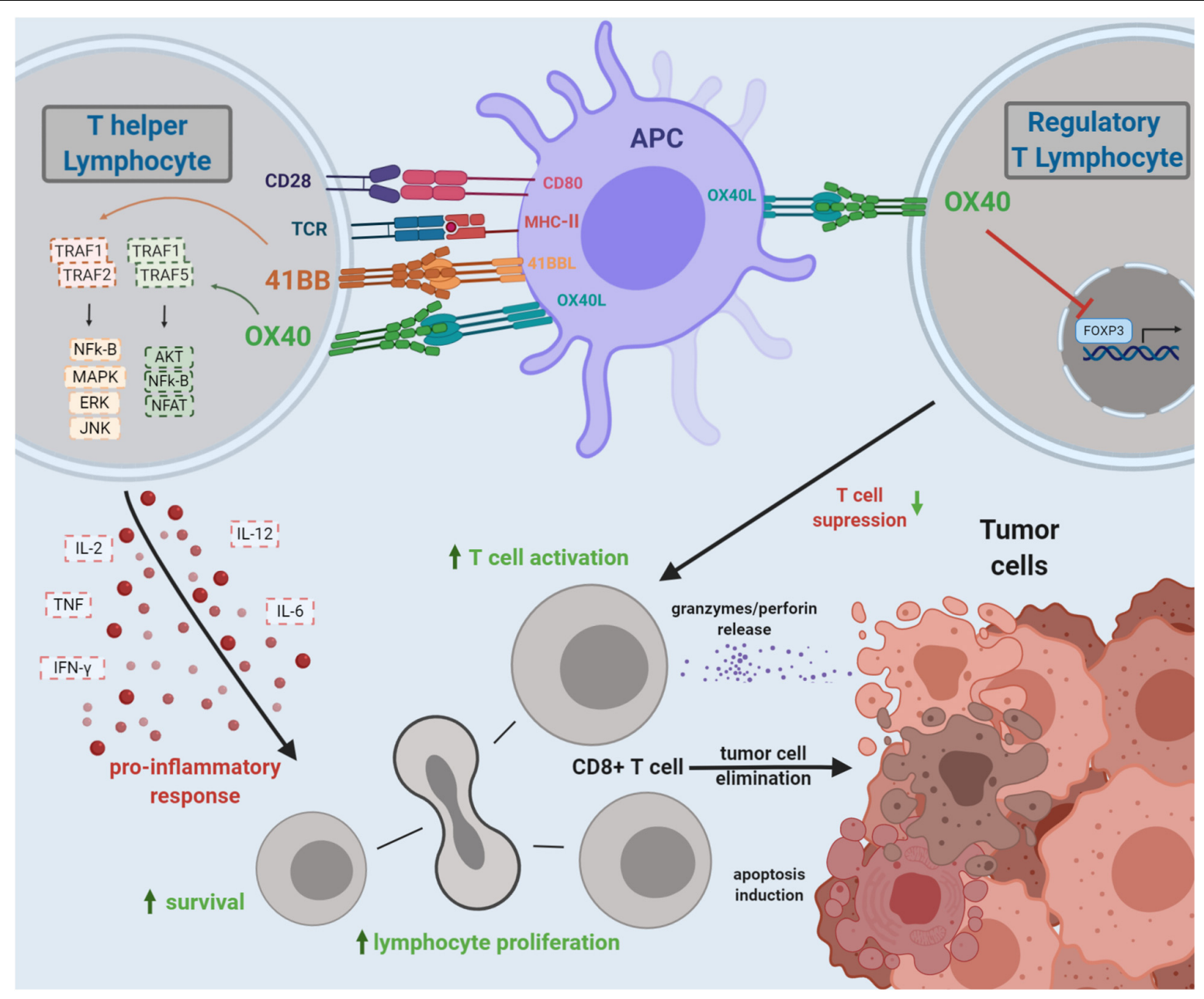

FIGURE 1 | Costimulation by 4-1BB and OX40 TCRs and the overall effects on antitumor T-cell immunity. 4-1BB and OX40 bind to their ligands, triggering a signaling cascade leading to T-cell activation and expansion of cytotoxic CD8 ${ }^{+} \mathrm{T}$ Iymphocytes. Costimulation of OX40 may also inhibit the FOXP3 transcription factor on $\mathrm{CD}^{+}{ }^{+} \mathrm{T}$ cells, impairing the Treg function, diminishing tumor immunosuppression, and boosting the antitumor immune response. The 4-1BB/4-1BBL signaling triggers biochemical signals that increase $T_{H} 1$ cytokines and suppress $T_{H} 2$ cytokines; potentiate activation, survival, proliferation, and cytotoxicity of $T_{\text {cells; }}$ and provoke the maturation of dendritic cells. The OX40/OX40L interaction triggers a signaling cascade, similar to 4-1BB/4-1BBL, inducing transcriptional changes to modulate the immune response. The OX40 costimulation may promote T-cell proliferation and survival. The agonistic signaling transduced by OX40 on Treg may impair FOXP3 expression, enhancing antitumor response.

The costimulatory 4-1BB signaling induces clonal expansion, proliferation, cytokine secretion, and long-term T-cell survival (Wen et al., 2002). The 4-1BB costimulation improves the mitochondrial function of $\mathrm{T}$ cells, leading to greater longevity and memory capacity of these cells (Menk et al., 2018). Although 4-1BB costimulation transduces a robust costimulatory signal, mainly acting on $\mathrm{CD}^{+} \mathrm{T}$ cells (Habib-Agahi et al., 2007), mice that constitutively express $4-1 \mathrm{BB}$ on $\mathrm{CD} 4^{+} \mathrm{T}$ cells exhibited heightened and sustained proliferative activity and enhancement of T-cell priming, driving $\mathrm{T}_{\mathrm{H}} 1$ immune responses, increasing the number of tumor-infiltrating lymphocytes (TILs) in tumor masses, augmenting IFN- $\gamma$ production by T-cell population, mediating tumor suppression, and prolonging mice survival (Kim et al., 2003). This persistence of $\mathrm{T}$ cells is crucial for the success of chimeric antigenic receptor (CAR) T-cell therapy.
The CAR has an extracellular domain that recognizes a target antigen, transducing a signaling to an intracellular domain that boosts T-cell activation. This technology is being used mainly in hematological cancers, with promising results (Kalos et al., 2011; Porter et al., 2011). CAR T cells may employ a cytoplasmic domain of 4-1BB molecule to enhance the antitumor efficacy, the so-called third generation of CART cells. The 4-1BB intracellular signaling domain provides a second costimulatory signal that makes the CAR T-cells more effective and long lasting (van der Stegen et al., 2015).

Similar to $4-1 \mathrm{BB} / 4-1 \mathrm{BBL}$, the OX40/OX40L pathway also triggers strong costimulatory signaling on $\mathrm{CD} 4^{+}$and $\mathrm{CD} 8^{+}$ $\mathrm{T}$ cells, although this effect is more prominent in $\mathrm{CD} 4^{+} \mathrm{T}$ cells (Xiao et al., 2004). The OX40 costimulatory signaling promotes the activation, expansion, proliferation, differentiation, 
proinflammatory cytokine production, supporting survival of T lymphocytes, and tumor regression (Rogers et al., 2001; Linch et al., 2016; Peng et al., 2019; Kuang et al., 2020). It was demonstrated that high expression of OX40 in the tumor-infiltrating immune cells in small cell lung cancer induced increased levels of IFN- $\gamma$ expression and favorable prognosis in patients (Massarelli et al., 2019). The OX40 costimulatory signaling on exhausted $\mathrm{CD}^{+} \mathrm{T}$ cells could rescue their proliferative potential and cytokine production (Buchan et al., 2015).

In addition, agonistic OX40 signaling in Tregs may impair the expression of FOXP3, which is a master key to regulate the Tregimmunosuppressive phenotype (So and Croft, 2007; Vu et al., 2007; Piconese et al., 2008). As Tregs may antagonize antitumor response inhibiting T-cell proliferation (Liu et al., 2009; Xu et al., 2010; Chang et al., 2012), the costimulation of OX40 may inhibit the immunosuppressive activity of Tregs and also the conversion of effector $\mathrm{T}$ (Teff) $\mathrm{CD}^{+} \mathrm{T}$ cells into a regulatory $\mathrm{T}$-cell phenotype (So and Croft, 2007; Piconese et al., 2008; Kitamura et al., 2009). The role of agonistic 4-1BB signaling on Tregs is controversial. Although most studies demonstrated 4-1BB agonistic signaling enhanced the immunosurveillance activity, there are other reports that describes immunosuppressive activity, as expanding Tregs (Irie et al., 2007; Zhang et al., 2007; Lubrano di Ricco et al., 2020).

\section{ENHANCING ANTITUMOR IMMUNITY BY AGONISTIC ANTIBODIES DRIVEN TO 4-1BB AND OX40 T-CELL COSTIMULATION}

The agonistic 4-1BB or OX40 costimulation by monoclonal antibodies (mAbs) is widely explored in cancer immunotherapy (Wilcox et al., 2002; Vinay and Kwon, 2014). There are several clinical trials exploring the therapeutic benefit of mAbs (Table 1). The TNFRSF-targeted costimulatory strategy may be used in combination with chemotherapy and radiotherapy, improving antitumor response (Shi and Siemann, 2006; Ju et al., 2008). 4-1BB agonist antibodies promote increased T-cell proliferation and survival. These antibodies may also activate NK cells (Klatzmann et al., 1984; Lin et al., 2008; Rajasekaran et al., 2015; Makkouk et al., 2016). The binding of an agonistic mAb induces 4-1BB cell surface receptor internalization, which may trigger signaling from endosomatic compartments, as the polyubiquitination of $\mathrm{K} 63$ to recruit TRAF2 and starting the T-cell activation cascade (MartinezForero et al., 2013). The agonistic 4-1BB antibody may act on depletion of Treg cells, and this stimulus seems to be associated with its $\mathrm{FC} \gamma \mathrm{R}$ engagement and antibody isotype. It was observed the immunoglobulin G1 (IgG1) mAb isotype induced an enhanced CD8 T-cell costimulation in an established solid tumor microenvironment. The IgG2a isotype has shown intratumoral Treg depletion and optimal antitumor activity in preclinical model (Buchan et al., 2018). The main 4-1BB agonist antibodies used in the clinic are utomilumab (PF-05082566) and urelumab (BMS-663513). Both mAbs are already being used in cancer clinical trials. Whereas the IgG2 utomilumab is safe with relatively low efficacy, the IgG4 urelumab has a great antitumor efficacy, but causes liver damage (Segal et al., 2014; Gopal et al., 2017; Tolcher et al., 2017). In addition, urelumab can induce a cluster of 4-1BBL-dependent receptors, unlike utomilumab (Chin et al., 2018). The preliminary results of urelumab trials in 2008 demonstrated efficacy against cancers in advanced stages. However, the treatment with $\mathrm{mAb}$ induced liver damage, interrupting the clinical trials. Toxicity is suggested as a consequence of Fc $\gamma$ RIIB-mediated $\mathrm{CD} 8^{+}$T-cell activation in the liver, once Fc $\gamma$ RIIB is expressed on liver sinusoidal endothelial cells and Kupffer cells (Qi et al., 2019). Urelumab has been evaluated as monotherapy or in combination with other drugs, such as rituximab, cetuximab, elotuzumab, and nivolumab, at lower doses, with no damage to the liver. When associated with rituximab, in the treatment of patients with relapsing or refractory non-Hodgkin lymphomas, the urelumab has demonstrated safety, tolerability, and improvement of the host immune response. Utomilumab promoted a long-lasting

TABLE 1 | Clinical protocols in progress using costimulatory anti-4-1BB and anti-OX40 monoclonal antibodies.

\begin{tabular}{|c|c|c|c|c|c|}
\hline mAbs & Target & Phase & Tumor & Combination & Protocol \\
\hline Utomilumab & 41BB & II & HER2 + Breast cancer & Avehnnab (anti-PD-LI) & NCT03414658 \\
\hline Utomilumab & $41 \mathrm{BB}$ & $\mathbf{I}$ & HER2 + Breast cancer & Trasluzumab (anti-HER2) & NCT03364348 \\
\hline AGEN2373 & 41BB & $\mathbf{I}$ & Advanced Solid Tumor & - & NCT04121676 \\
\hline MEDI0562 & OX40 & $\mathbf{I}$ & Head/Neck squamous cell carcinoma Melanoma & - & NCT03336606 \\
\hline INBRX-106 & OX40 & 1 & Locally Advanced/Metastatic tumor & Pembrolizumab & NCT04198766 \\
\hline PF04518600 & OX40 & I/II & Acute myeloid leukemia & Avelumab (anti-PD-LI) Azacitidine & NCT03390296 \\
\hline PF04518600 & OX40 & II & Metastatic kidney cancer & Axitinib (TK inhibitor) & NCT03092856 \\
\hline PF04518600 & OX40 & II & Triple negative breast cancer & Avelumab (anti-PD-LI) & NCT03971409 \\
\hline PF-04518600 & OX40 & $\mathrm{I} / \mathrm{II}$ & Advanced malignancies & Avelumab (antiPD-LI) Radiation & NCT03217747 \\
\hline
\end{tabular}


response and reduced toxicity in patients with lymphomas. This $\mathrm{mAb}$ is being extensively tested in combination with other immunotherapies for different tumors, such as non-small cell lung cancer, kidney, head, and neck cancer (Tolcher et al., 2017; Gopal et al., 2020).

Innovative strategies based on bispecific antibodies also may be used to overcome systemic toxicity of agonistic 4-1BB, targeting the costimulatory activity to tumor site. A bispecific 4-1BB/HER-2 antibody was engineered to bind HER-2-positive tumor cells and to costimulate $\mathrm{T}$ cells. This bispecific antibody was shown to inhibit tumor growth in humanized mice model (Hinner et al., 2019).

In addition to the costimulatory $4-1 \mathrm{BB}$ mAbs, several studies have also demonstrated the antitumor effect of OX40 agonist antibodies. Mice treated with OX40 mAbs accumulated CD4 ${ }^{+}$ $\mathrm{T}$ cells and augmented $\mathrm{CD} 4^{+}$T-cell survival and developing memory T cells (Cannons et al., 2001; Tolcher et al., 2017). The OX40 agonistic antibody may inhibit immune tolerance (Gramaglia et al., 2000; Maxwell et al., 2000).

The use of OX40 agonistic antibody in preclinical models has shown tumor regression in sarcomas, melanoma, colon carcinoma, and glioma (Kjaergaard et al., 2000; Weinberg et al., 2000; Andarini et al., 2004). In several preclinical and clinical models, OX40 agonist antibodies induce tumor regression due to their ability to prevent the suppression of antitumor immune responses mediated by Tregs. The OX40 costimulation may inhibit Treg activity in three different ways: (i) inhibiting the activity of natural Treg or even the conversion of $\mathrm{T}$ cells to Treg phenotype, due to impairing of FOXP3 expression (So and Croft, 2007; Vu et al., 2007; Song et al., 2008); (ii) reducing the suppressive activity by increasing the production of IL-2 and other cytokines (Valzasina et al., 2005); and (iii) depleting intratumoral Treg cells in an Fc $\gamma$ R-dependent manner (Bulliard et al., 2014).

A phase I clinical trial in patients, with incurable metastatic carcinoma, lymphoma, or sarcoma (NCT01644968), using 9B12, a murine agonistic anti-human OX40 mAb, demonstrated that OX40 mAb treatment induced proliferation of $\mathrm{CD}_{4}^{+}$ and $\mathrm{CD}^{+} \mathrm{T}$ cells and NK cells, enhanced production of IFN- $\gamma$ by $\mathrm{CD}^{+} \mathrm{T}$ cells, boosted T- and B-cell antitumor reactivity, and increased memory $\mathrm{T}$ cells (Curti et al., 2013). The MOXR 0916, also known as pogalizumab, is a humanized agonistic IgG antibody specific for OX40 that has immunostimulatory and antineoplastic activities. Pogalizumab binds and selectively activates OX40. The activation of OX40 promotes the proliferation of Teff lymphocytes and inhibits the activity of Treg cells in the presence of tumor antigens (Infante et al., 2016).

The combination of agonistic OX40 mAb to the PDL1 inhibitor atezolizumab is being tested in patients who have advanced solid neoplasms (NCT02410512). Recently, Kuang et al. (2020) reported the development of a new anti-OX40 antibody, the IBI101. This mAb promotes both Fc $\gamma \mathrm{R}$-dependent and independent agonistic activities. The combination of IBI101 and anti-PD-L1 has shown a better inhibition of tumor growth in mice model, when compared to the combination of pogalizumab and anti-PD-L1 (Kuang et al., 2020).
There are several clinical trials exploring the application of costimulatory anti-OX40 mAbs as adjuvants in other therapies, as anti-OX40 combined to chemotherapy and radiotherapy (NCT01303705), anti-OX40 combined to other immunotherapy and chemotherapy (NCT03390296), and anti-OX40 combined to radiotherapy (NCT01862900, NCT02559024), among others.

\section{AGONISTIC SIGNALING STRATEGIES MEDIATED BY THE TNFSF LIGANDS 4-1BBL AND OX40L POTENTIATE T CELL-MEDIATED ANTITUMOR RESPONSE}

As reported above, agonistic TNFRSF-driven antibodies may exhibit toxicity associated with the systemic use, as the expression of TNFRs is ubiquitous, and, consequently, the action of these antibodies is not specific to tumor microenvironment (Ascierto et al., 2010). Therefore, a challenge faced by researchers is to induce a tumor-specific effect, which may reduce toxicity. Back in 2009, the group of Shirwan has developed a murine recombinant 4-1BBL molecule fused to streptavidin (SA-4$1 \mathrm{BBL}$ ) that exhibited less toxicity when compared to agonistic antibody, lacking Fc $\gamma \mathrm{R}$ activation (Schabowsky et al., 2009). SA4-1BBL forms tetramers and oligomers in soluble form, inducing a powerful T-cell costimulatory activity. Further studies have shown this molecule to be safe and effective in murine model of cervical cancer (Sharma et al., 2010). SA-4-1BBL could induce an efficient $\mathrm{CD} 4^{+} \mathrm{T}$-cell activation while blocking the development of $\mathrm{CD}^{+}$Tregs, increasing the Teff-to-Treg ratio (Curti et al., 2013). Prophylactic administration of SA-4-1BBL to tumorchallenged mice was shown to prevent tumor growth, and this was dependent on $\mathrm{CD}^{+} \mathrm{T}$ cell, NK, and IFN- $\gamma$ production (Barsoumian et al., 2016).

Murine studies with 4-1BBL have shown that NK cells are activated and may respond to the antitumor activity due to 41BBL administration (Houot et al., 2009). Dowell et al. have demonstrated that stimulation of human PBMC, both from healthy donors and ovarian carcinoma patients with soluble 4-1BBL and IL-2, promoted expansion of $\mathrm{CD} 56^{+} \mathrm{NK}$ cells (Dowell et al., 2012). Cancer cells transduced with 4-1BBL promote expansion of cytotoxic T cells (Sharma et al., 2010; Barsoumian et al., 2016), as well as NK cells (Gong et al., 2010). It was also observed that stimulation of human NK cells with recombinant 4-1BBL (rh4-1BB) in combination to anti-HER-2 therapy (trastuzumab) enhanced antitumor cytotoxicity in gastric cancer cells (Misumi et al., 2018).

The 4-1BBL has also been used in cell-based strategies to stimulate TILs. Gene-pulsed DCs with 4-1BBL enhanced IFN- $\gamma$ production and T-cell activation (Youlin et al., 2013). A lipid-based nanoparticle harboring $4-1 \mathrm{BBL}$ is being used for T-cell costimulation, in clinical trials for cancer therapy (NCT03323398, NCT03739931).

As seen for 4-1BBL, the OX40L-expressing cells also stimulate antitumor response. Intratumoral administration of OX40L-expressing DCs promoted the generation of 
tumor-specific $\mathrm{CD}^{+}$and NK T cells, contributing to impaired tumor growth (Zaini et al., 2007). Modification of tumor cells with an adenovirus encoding OX40L promoted an efficient $\mathrm{T}_{\mathrm{H}} 1$ immune response associated with cytotoxic $\mathrm{T}$ lymphocytes (Andarini et al., 2004).

As observed for combinations of costimulatory mAbs, the OX40L and 4-1BBL dual costimulation has been shown to be effective in reducing tumor growth and enhances mainly the $\mathrm{CD}^{+}$T-cell response (Weinberg et al., 2000; Cuadros et al., 2005; Lee et al., 2006; Gray et al., 2008; Redmond et al., 2009; Manrique-Rincón et al., 2017). We and others have shown that the synergy between OX40/OX40L and 4-1BB/4-1BBL also contributes to enhance antitumor immune response (Lee et al., 2004, 2006; Munks et al., 2004; Manrique-Rincón et al., 2017; Fu et al., 2020). Indeed, our group has previously developed tumorderived vaccines using B16 melanoma cells line, transduced with 4-1BBL and/or OX40L. We have shown that combination of these vaccines increased antitumor T cell-mediated cytotoxicity, reduction of Tregs, and contributing to tumor rejection in vivo, besides generating a protective effect on rechallenged animals (Manrique-Rincón et al., 2017). Moreover, extracellular vesicles (EVs) secreted by 4-1BBL and OX40L B16 vaccines were shown to induce T-cell proliferation and inhibit the generation of inducible Treg in vitro (Semionatto et al., 2020). These findings highlight the exploration of tumor-derived EVs as a potential tool for immunotherapy (Zaini et al., 2007).

\section{OLIGONUCLEOTIDE-DERIVED APTAMERS MAY BE ENGINEERED AS COSTIMULATORY MOLECULES TO ENHANCE ANTITUMOR IMMUNITY}

Aptamers are small molecules of single-stranded RNA or DNA oligonucleotides that may exhibit high affinity and selectivity for targets (Ellington and Szostak, 1990; Tuerk and Gold, 1990). These molecules exhibit similar properties to antibodies and may have some advantages: (i) aptamers are chemically synthesized and (ii) exhibit high tissue permeability and cell internalization due to its reduced size; (iii) aptamers usually exhibit low toxicity and immunogenicity, and (iv) aptamers may be inactivated by an antidote (Ellington and Szostak, 1990; Bompiani et al., 2012; Cheng et al., 2013; Bouvier-Müller and Ducongé, 2018).

Several aptamer-based therapeutic application has been explored for cancer (Morita et al., 2018; Maimaitiyiming et al., 2019).

Preclinical studies have demonstrated an equivalent or even superior functionality of these oligonucleotides compared to mAb molecules, as well as a decrease of the commonly observed side effects of mAbs (Miller and Chapman, 2001; Dollins et al., 2008; McNamara et al., 2008; Pastor et al., 2011; Pratico et al., 2013; Schrand et al., 2014, 2015; Rajagopalan et al., 2017). Aptamers may be employed as antagonist, agonist, and delivery tools (Pastor et al., 2018). The first aptamer driven to tumor immunomodulation was an antagonist CTLA-4 aptamer, and then, a number of new aptamers with immunomodulatory activity have been proposed (Santulli-Marotto et al., 2003).

As T-cell surface receptors such as TNFRSF are activated because of cross-link, multivalent aptamer models have been explored to lead T-cell activation and costimulation (Dollins et al., 2008; McNamara et al., 2008; Pratico et al., 2013). The possibility of using synthetic linkers of different size and composition was shown. This multimerization strategy allowed to generate functional aptamer molecules that could costimulate 4-1BB and OX40 receptors in $\mathrm{T}$ cells that would address improvement of the antitumor immune response (Dollins et al., 2008; McNamara et al., 2008). These studies have shown that treatment with aptamers induces a costimulatory effect on tumor environment comparable to the treatment with the corresponding mAb (Dollins et al., 2008; McNamara et al., 2008; Pratico et al., 2013).

Considering the side effects of systemic administration of mAb 4-1BB (Niu et al., 2007) due to plasticity of engineering, aptamers have been investigated to overcome toxicity, opening a new field of research based on bispecific aptamers. The aim of these approaches is to decrease the off-target effect by driving the costimulatory effect specifically on target cells (Pastor et al., 2011; Schrand et al., 2014, 2015). A first study involving a proof of concept of these aptamers developed a bifunctional 4-1BB-prostate-specific membrane antigen (PSMA) conjugate. The PSMA is a membrane antigen highly expressed in some prostate cells. In this way, the $4-1 \mathrm{BB}$ portion had a T-cell costimulatory activity, whereas the PSMA portion could drive the molecule to PSMA-expressing tumor cells. The study showed that systemic administrations of bispecific aptamer were able to inhibit tumor growth with the administration of a 10-fold lower dose without occurrence of side effects (Pastor et al., 2011).

Another technological approach that has been pursued is the generation of chimeric aptamer to vehiculate siRNA to target cells. Aptamers may bind to cell surface receptors to deliver siRNA to the target cell. This approach is target specific and may reduce possible off-target effects, improving the therapeutic index of the use of siRNA as drug treatment (Berezhnoy et al., 2012). A functional study has shown that 4-1BB aptamer was conjugated to a siRNA that negatively regulate the mTOR pathway, decreasing the generation of memory cells in treated animals (Berezhnoy et al., 2014).

Despite the variety of preclinical studies involving aptamer molecules for 4-1BB and OX40 and the positive results achieved, these molecules have not been tested in clinical studies yet. The use of aptamer molecules as a therapeutic strategy is considered recent when compared to mAbs, and it has raised attention in the scientific community, proving its safety profile with the first drug approved for clinical use (Ng et al., 2006) and with other molecules being pursued for clinical study in the field of tumor immunology (Zboralski et al., 2017; Steurer et al., 2019).

\section{CONCLUSION}

The 4-1BB and OX40 TNFRSF receptors are associated with several signaling that contribute to potentiate T-cell antitumor 
activity. Agonistic antibodies are widely used in clinical trials and represent the most explored TNFSF-based costimulatory strategies. The development of agonistic oligonucleotide-derived aptamers driven to TNFSFR elements is also an interesting alternative to antibodies because of the simplicity of production through chemical synthesis and engineering possibilities to generate bispecific aptamers or even vehiculated targeted cargos to enhance T-cell function. Signal transduction at TNFSFR receptors can also be mediated by approaches using 4-1BBL or OX40L ligands. These ligands may be expressed in antitumor vaccines or even used in soluble form, exhibiting therapeutic effect. The costimulatory potential of TNFSF molecules is also explored for T-cell engineering, such as chimeric receptors that encode 4-1BB intracellular domains, which are known to play an important role in the costimulation and maintenance of the activated lymphocyte phenotype. Therapeutic strategies that employ 4-1BB and OX40 costimulation work to switch the balance of the

\section{REFERENCES}

Alderson, M. R., Smith, C. A., Tough, T. W., Davis-Smith, T., Armitage, R. J., Falk, B., et al. (1994). Molecular and biological characterization of human 4-1BB and its ligand. Eur. J. Immunol. 24, 2219-2227.

Andarini, S., Kikuchi, T., Nukiwa, M., Pradono, P., Suzuki, T., Ohkouchi, S., et al. (2004). Adenovirus vector-mediated in vivo gene transfer of OX40 ligand to tumor cells enhances antitumor immunity of tumor-bearing hosts. Cancer Res. 64, 3281-3287. doi: 10.1158/0008-5472.can-03-3911

Arch, R. H., and Thompson, C. B. (1998). 4-1BB and Ox40 are members of a tumor necrosis factor (TNF)-nerve growth factor receptor subfamily that bind TNF receptor-associated factors and activate nuclear factor kappaB. Mol. Cell. Biol. 18, 558-565. doi: 10.1128/mcb.18.1.558

Ascierto, P. A., Simeone, E., Sznol, M., Fu, Y.-X., and Melero, I. (2010). Clinical experiences with anti-CD137 and anti-PD1 therapeutic antibodies. Semin Oncol. 37, 508-516. doi: 10.1053/j.seminoncol.2010.09.008

Bansal-Pakala, P., Halteman, B. S., Cheng, M. H.-Y., and Croft, M. (2004). Costimulation of CD8 T cell responses by OX40. J. Immunol. 172, 4821-4825. doi: 10.4049/jimmunol.172.8.4821

Barsoumian, H. B., Yolcu, E. S., and Shirwan, H. (2016). 4-1BB signaling in conventional $\mathrm{T}$ cells drives IL-2 production that overcomes CD4+CD25+FoxP3+ Tregulatory cell suppression. PLoS One 11:e0153088. doi: 10.1371/journal.pone.0153088

Baumann, R., Yousefi, S., Simon, D., Russmann, S., Mueller, C., and Simon, H.-U. (2004). Functional expression of CD134 by neutrophils. Eur. J. Immunol. 34, 2268-2275. doi: 10.1002/eji.200424863

Berezhnoy, A., Brenneman, R., Bajgelman, M., Seales, D., and Gilboa, E. (2012). Thermal stability of siRNA modulates aptamer- conjugated siRNA inhibition. Mol. Ther. Nucleic Acids 1:e51. doi: 10.1038/mtna.2012.41

Berezhnoy, A., Castro, I., Levay, A., Malek, T. R., and Gilboa, E. (2014). Aptamertargeted inhibition of mTOR in T cells enhances antitumor immunity. J. Clin. Invest. 124, 188-197. doi: 10.1172/jci69856

Bompiani, K. M., Monroe, D. M., Church, F. C., and Sullenger, B. A. (2012). A high affinity, antidote-controllable prothrombin and thrombin-binding RNA aptamer inhibits thrombin generation and thrombin activity. J. Thromb. Haemost. 10, 870-880. doi: 10.1111/j.1538-7836.2012.04679.x

Bouvier-Müller, A., and Ducongé, F. (2018). Application of aptamers for in vivo molecular imaging and theranostics. Adv. Drug Deliv. Rev. 134, 94-106. doi: 10.1016/j.addr.2018.08.004

Bouwmeester, T., Bauch, A., Ruffner, H., Angrand, P.-O., Bergamini, G., Croughton, K., et al. (2004). A physical and functional map of the human TNF-alpha/NF-kappa B signal transduction pathway. Nat. Cell Biol. 6, 97-105.

Buchan, S., Manzo, T., Flutter, B., Rogel, A., Edwards, N., Zhang, L., et al. (2015). OX40- and CD27-mediated costimulation synergizes with anti-PD-L1 blockade immune system toward immunosurveillance. These strategies can also be associated with immunological checkpoint inhibitors, which target the inhibition of immunosuppression mechanisms favoring the detection and elimination of tumor cells.

\section{AUTHOR CONTRIBUTIONS}

All authors listed have made a substantial, direct and intellectual contribution to the work, and approved it for publication.

\section{FUNDING}

MB - FAPESP, grant 2019/04458-8, IS - FAPESP, PhD fellowship 2018/16449-0, CF - FAPESP, fellowship 2019/13573-5, GL FAPESP, fellowship 2019/150491, RR - CAPES PhD fellowship, DM - CAPES M.Sc fellowship.

by forcing exhausted CD8+ T cells to exit quiescence. J. Immunol. 194, 125-133. doi: 10.4049/jimmunol.1401644

Buchan, S. L., Dou, L., Remer, M., Booth, S. G., Dunn, S. N., Lai, C., et al. (2018). Antibodies to costimulatory receptor 4-1BB enhance antitumor immunity via $\mathrm{T}$ regulatory cell depletion and promotion of CD8 T cell effector function. Immunity 49, 958-970.e7. doi: 10.1016/j.immuni.2018. 09.014

Bukczynski, J., Wen, T., and Watts, T. H. (2003). Costimulation of human CD28T cells by 4-1BB ligand. Eur. J. Immunol. 33, 446-454. doi: 10.1002/immu. 200310020

Bulliard, Y., Jolicoeur, R., Zhang, J., Dranoff, G., Wilson, N. S., and Brogdon, J. L. (2014). OX40 engagement depletes intratumoral Tregs via activating Fc $\gamma$ Rs, leading to antitumor efficacy. Immunol. Cell Biol. 92, 475-480. doi: 10.1038/ icb. 2014.26

Calderhead, D. M., Buhlmann, J. E., van den Eertwegh, A. J., Claassen, E., Noelle, R. J., and Fell, H. P. (1993). Cloning of mouse Ox40: a T cell activation marker that may mediate T-B cell interactions. J. Immunol. 151, 5261-5271.

Cannons, J. L., Choi, Y., and Watts, T. H. (2000). Role of TNF receptor-associated factor 2 and p38 mitogen-activated protein kinase activation during 4-1BBdependent immune response. J. Immunol. 165, 6193-6204. doi: 10.4049/ jimmunol.165.11.6193

Cannons, J. L., Lau, P., Ghumman, B., DeBenedette, M. A., Yagita, H., Okumura, K., et al. (2001). 4-1BB ligand induces cell division, sustains survival, and enhances effector function of CD4 and CD8 T cells with similar efficacy. J. Immunol. 167, 1313-1324. doi: 10.4049/jimmunol.167. 3.1313

Chang, L.-Y., Lin, Y.-C., Mahalingam, J., Huang, C.-T., Chen, T.-W., Kang, C.W., et al. (2012). Tumor-derived chemokine CCL5 enhances TGF- $\beta$-mediated killing of CD8(+) T cells in colon cancer by T-regulatory cells. Cancer Res. 72, 1092-1102. doi: 10.1158/0008-5472.can-11-2493

Chen, D. S., and Mellman, I. (2013). Oncology meets immunology: the cancerimmunity cycle. Immunity 39, 1-10. doi: 10.1016/j.immuni.2013.07.012

Cheng, C., Chen, Y. H., Lennox, K. A., Behlke, M. A., and Davidson, B. L. (2013). In vivo SELEX for Identification of brain-penetrating aptamers. Mol. Ther. Nucleic Acids 2:e67. doi: 10.1038/mtna.2012.59

Chin, S. M., Kimberlin, C. R., Roe-Zurz, Z., Zhang, P., Xu, A., Liao-Chan, S., et al. (2018). Structure of the $4-1 \mathrm{BB} / 4-1 \mathrm{BBL}$ complex and distinct binding and functional properties of utomilumab and urelumab. Nat. Commun. 9:4679. doi: 10.1038/s41467-018-07136-7

Cuadros, C., Dominguez, A. L., Lollini, P.-L., Croft, M., Mittler, R. S., Borgström, P., et al. (2005). Vaccination with dendritic cells pulsed with apoptotic tumors in combination with anti-OX40 and anti-4-1BB monoclonal antibodies induces $\mathrm{T}$ cell-mediated protective immunity in Her-2/neu transgenic mice. Int. J. Cancer 116, 934-943. doi: 10.1002/ijc.21098 
Curti, B. D., Kovacsovics-Bankowski, M., Morris, N., Walker, E., Chisholm, L., Floyd, K., et al. (2013). OX40 is a potent immune-stimulating target in latestage cancer patients. Cancer Res. 73, 7189-7198. doi: 10.1158/0008-5472.can12- 4174

Dawicki, W., Bertram, E. M., Sharpe, A. H., and Watts, T. H. (2004). 4-1BB and OX40 act independently to facilitate robust CD8 and CD4 recall responses. J. Immunol. 173, 5944-5951. doi: 10.4049/jimmunol.173.10.5944

De Smedt, T., Smith, J., Baum, P., Fanslow, W., Butz, E., and Maliszewski, C. (2002). Ox40 costimulation enhances the development of $\mathrm{T}$ cell responses induced by dendritic cells in vivo. J. Immunol. 168, 661-670. doi: 10.4049/jimmunol.168.2. 661

DeBenedette, M. A., Shahinian, A., Mak, T. W., and Watts, T. H. (1997). Costimulation of CD28- T lymphocytes by 4-1BB ligand. J. Immunol. 158, 551-559.

Dollins, C. M., Nair, S., Boczkowski, D., Lee, J., Layzer, J. M., Gilboa, E., et al. (2008). Assembling OX40 aptamers on a molecular scaffold to create a receptoractivating aptamer. Chem. Biol. 15, 675-682. doi: 10.1016/j.chembiol.2008.05. 016

Dowell, A. C., Oldham, K. A., Bhatt, R. I., Lee, S. P., and Searle, P. F. (2012). Long-term proliferation of functional human NK cells, with conversion of CD56(dim) NK cells to a CD56 (bright) phenotype, induced by carcinoma cells co-expressing 4-1BBL and IL-12. Cancer Immunol. Immunother. 61, 615-628. doi: $10.1007 / \mathrm{s} 00262-011-1122-3$

Ellington, A. D., and Szostak, J. W. (1990). In vitro selection of RNA molecules that bind specific ligands. Nature 346, 818-822. doi: 10.1038/346818a0

Froelich, C. J., Orth, K., Turbov, J., Seth, P., Gottlieb, R., Babior, B., et al. (1996). New paradigm for lymphocyte granule-mediated cytotoxicity. Target cells bind and internalize granzyme $\mathrm{B}$, but an endosomolytic agent is necessary for cytosolic delivery and subsequent apoptosis. J. Biol. Chem. 271, 29073-29079. doi: $10.1074 /$ jbc. 271.46 .29073

Fröhlich, A., Loick, S., Bawden, E. G., Fietz, S., Dietrich, J., Diekmann, E., et al. (2020). Comprehensive analysis of tumor necrosis factor receptor TNFRSF9 (4-1BB) DNA methylation with regard to molecular and clinicopathological features, immune infiltrates, and response prediction to immunotherapy in melanoma. EBioMedicine 52, 1-14.

Fu, Y., Lin, Q., Zhang, Z., and Zhang, L. (2020). Therapeutic strategies for the costimulatory molecule OX40 in T-cell-mediated immunity. Acta Pharm. Sin. B 10, 414-433. doi: 10.1016/j.apsb.2019.08.010

Gajdasik, D. W., Gaspal, F., Halford, E. E., Fiancette, R., Dutton, E. E., Willis, C., et al. (2020). Th1 responses in vivo require cell-specific provision of OX40L dictated by environmental cues. Nat. Commun. 11:3421. doi: 10.1038/s41467020-17293-3

Godfrey, W. R., Fagnoni, F. F., Harara, M. A., Buck, D., and Engleman, E. G. (1994). Identification of a human OX-40 ligand, a costimulator of CD4+ T cells with homology to tumor necrosis factor. J. Exp. Med. 180, 757-762. doi: 10.1084/jem.180.2.757

Gong, W., Xiao, W., Hu, M., Weng, X., Qian, L., Pan, X., et al. (2010). Ex vivo expansion of natural killer cells with high cytotoxicity by K562 cells modified to co-express major histocompatibility complex class I chain-related protein A, 4-1BB ligand, and interleukin-15. Tissue Antigens 76, 467-475. doi: 10.1111/j. 1399-0039.2010.01535.x

Goodwin, R. G., Din, W. S., Davis-Smith, T., Anderson, D. M., Gimpel, S. D., Sato, T. A., et al. (1993). Molecular cloning of a ligand for the inducible T cell gene 4-1BB: a member of an emerging family of cytokines with homology to tumor necrosis factor. Eur. J. Immunol. 23, 2631-2641. doi: 10.1002/eji.1830231037

Gopal, A., Levy, R., Houot, R., Patel, S., Hatake, K., Popplewell, L., et al. (2017). A phase I study of utomilumab (PF-05082566), A 4-1BB/CD137 agonist, in combination with rituximab in patients with CD20+ Non-Hodgkin's Lymphoma. Hematol. Oncol. 35:260. doi: 10.1002/hon.2438_127

Gopal, A. K., Levy, R., Houot, R., Patel, S. P., Popplewell, L., Jacobson, C., et al. (2020). First-in-human study of utomilumab, a 4-1BB/CD137 agonist, in combination with rituximab in patients with follicular and other CD20(+) NonHodgkin Lymphomas. Clin. Cancer Res. 26, 2524-2534. doi: 10.1158/10780432.ccr-19-2973

Gramaglia, I., Jember, A., Pippig, S. D., Weinberg, A. D., Killeen, N., and Croft, M. (2000). The OX40 costimulatory receptor determines the development of CD4 memory by regulating primary clonal expansion. J. Immunol. 165, 3043-3050. doi: 10.4049/jimmunol.165.6.3043
Gray, J. C., French, R. R., James, S., Al-Shamkhani, A., Johnson, P. W., and Glennie, M. J. (2008). Optimising anti-tumour CD8 T-cell responses using combinations of immunomodulatory antibodies. Eur. J. Immunol. 38, 2499-2511. doi: 10. 1002/eji.200838208

Habib-Agahi, M., Phan, T. T., and Searle, P. F. (2007). Co-stimulation with 41BB ligand allows extended T-cell proliferation, synergizes with CD80/CD86 and can reactivate anergic T cells. Int. Immunol. 19, 1383-1394. doi: 10.1093/ intimm/dxm106

Hinner, M. J., Aiba, R. S. B., Jaquin, T. J., Berger, S., Dürr, M. C., Schlosser, C., et al. (2019). Tumor-localized costimulatory T-cell engagement by the 4-1BB/HER2 bispecific antibody-anticalin fusion PRS-343. Clin. Cancer Res. 25, 5878-5889. doi: 10.1158/1078-0432.ccr-18-3654

Hockenbery, D., Nuñez, G., Milliman, C., Schreiber, R. D., and Korsmeyer, S. J. (1990). Bcl-2 is an inner mitochondrial membrane protein that blocks programmed cell death. Nature 348, 334-336. doi: 10.1038/348334a0

Houot, R., Goldstein, M. J., Kohrt, H. E., Myklebust, J. H., Alizadeh, A. A., Lin, J. T., et al. (2009). Therapeutic effect of CD137 immunomodulation in lymphoma and its enhancement by Treg depletion. Blood 114, 3431-3438. doi: 10.1182/ blood-2009-05-223958

Hurtado, J. C., Kim, Y. J., and Kwon, B. S. (1997). Signals through 4-1BB are costimulatory to previously activated splenic $\mathrm{T}$ cells and inhibit activationinduced cell death. J. Immunol. 158, 2600-2609.

Infante, J. R., Ahlers, C. M., Hodi, F. S., Postel-Vinay, S., Schellens, J. H. M., Heymach, J., et al. (2016). ENGAGE-1: a first in human study of the OX40 agonist GSK3174998 alone and in combination with pembrolizumab in patients with advanced solid tumors. J. Clin. Oncol. 34(15_Suppl.):TS3107. doi: 10.1200/ JCO.2016.34.15_suppl.TPS3107

Irie, J., Wu, Y., Kachapati, K., Mittler, R. S., and Ridgway, W. M. (2007). Modulating protective and pathogenic CD4+ subsets via CD137 in type 1 diabetes. Diabetes 56, 186-196. doi: 10.2337/db06-0793

Jang, I. K., Lee, Z. H., Kim, Y. J., Kim, S. H., and Kwon, B. S. (1998). Human 41BB (CD137) signals are mediated by TRAF2 and activate nuclear factor-kappa B. Biochem. Biophys. Res. Commun. 242, 613-620. doi: 10.1006/bbrc.1997. 8016

Jenkins, S. J., Perona-Wright, G., Worsley, A. G. F., Ishii, N., and MacDonald, A. S. (2007). Dendritic cell expression of OX40 ligand acts as a costimulatory, not polarizing, signal for optimal Th2 priming and memory induction in vivo. J. Immunol. 179, 3515-3523. doi: 10.4049/jimmunol.179.6.3515

Ju, S.-A., Cheon, S.-H., Park, S.-M., Tam, N. Q., Kim, Y. M., An, W. G., et al. (2008). Eradication of established renal cell carcinoma by a combination of 5fluorouracil and anti-4-1BB monoclonal antibody in mice. Int. J. Cancer 122, 2784-2790. doi: 10.1002/ijc.23457

Kalos, M., Levine, B. L., Porter, D. L., Katz, S., Grupp, S. A., Bagg, A., et al. (2011). T cells with chimeric antigen receptors have potent antitumor effects and can establish memory in patients with advanced leukemia. Sci. Transl. Med. 3:95ra73. doi: 10.1126/scitranslmed.3002842

Karulf, M., Kelly, A., Weinberg, A. D., and Gold, J. A. (2010). OX40 ligand regulates inflammation and mortality in the innate immune response to sepsis. J. Immunol. 185, 4856-4862. doi: 10.4049/jimmunol.1000404

Kim, D.-H., Chang, W.-S., Lee, Y.-S., Lee, K.-A., Kim, Y.-K., Kwon, B. S., et al. (2008). 4-1BB engagement costimulates NKT cell activation and exacerbates NKT cell ligand-induced airway hyperresponsiveness and inflammation. J. Immunol. 180, 2062-2068. doi: 10.4049/jimmunol.180.4.2062

Kim, J., Choi, S. P., La, S., Seo, J.-S., Kim, K. K., Nam, S. H., et al. (2003). Constitutive expression of 4-1BB on T cells enhances CD4+ T cell responses. Exp. Mol. Med. 35, 509-517. doi: 10.1038/emm.2003.66

Kim, Y. J., Kim, S. H., Mantel, P., and Kwon, B. S. (1998). Human 4-1BB regulates CD28 co-stimulation to promote Th1 cell responses. Eur. J. Immunol. 28, 881890. doi: 10.1002/(sici)1521-4141(199803)28:03<881::aid-immu881>3.0.co;20

Kitamura, N., Murata, S., Ueki, T., Mekata, E., Reilly, R. T., Jaffee, E. M., et al. (2009). OX40 costimulation can abrogate Foxp3+ regulatory T cell-mediated suppression of antitumor immunity. Int. J. Cancer 125, 630-638. doi: 10.1002/ ijc. 24435

Kjaergaard, J., Tanaka, J., Kim, J. A., Rothchild, K., Weinberg, A., and Shu, S. (2000). Therapeutic efficacy of OX-40 receptor antibody depends on tumor immunogenicity and anatomic site of tumor growth. Cancer Res. 60, 55145521. 
Klatzmann, D., Barré-Sinoussi, F., Nugeyre, M. T., Danquet, C., Vilmer, E., Griscelli, C. et al. (1984). Selective tropism of lymphadenopathy associated virus (LAV) for helper-inducer T lymphocytes. Science 225, 59-63. doi: 10.1126/ science.6328660

Kuang, Z., Jing, H., Wu, Z., Wang, J., Li, Y., Ni, H., et al. (2020). Development and characterization of a novel anti-OX40 antibody for potent immune activation. Cancer Immunol. Immunother. 69, 939-950. doi: 10.1007/s00262-020-02501-2

Kwon, B. S., and Weissman, S. M. (1989). cDNA sequences of two inducible T-cell genes. Proc. Natl. Acad. Sci. U.S.A. 86, 1963-1967. doi: 10.1073/pnas.86.6.1963

Laderach, D., Movassagh, M., Johnson, A., Mittler, R. S., and Galy, A. (2002). 4$1 \mathrm{BB}$ co-stimulation enhances human $\mathrm{CD} 8(+) \mathrm{T}$ cell priming by augmenting the proliferation and survival of effector CD8(+) T cells. Int. Immunol. 14, 1155-1167. doi: 10.1093/intimm/dxf080

Langstein, J., Michel, J., Fritsche, J., Kreutz, M., Andreesen, R., and Schwarz, H. (1998). CD137 (ILA/4-1BB), a member of the TNF receptor family, induces monocyte activation via bidirectional signaling. J. Immunol. 160, 2488-2494.

Latza, U., Dürkop, H., Schnittger, S., Ringeling, J., Eitelbach, F., Hummel, M., et al. (1994). The human OX40 homolog: cDNA structure, expression and chromosomal assignment of the ACT35 antigen. Eur. J. Immunol. 24, 677-683. doi: 10.1002/eji.1830240329

Lee, H.-W., Park, S.-J., Choi, B. K., Kim, H. H., Nam, K.-O., and Kwon, B. S. (2002). 4-1BB promotes the survival of CD8+ T lymphocytes by increasing expression of Bcl-xL and Bfl-1. J. Immunol. 169, 4882-4888. doi: 10.4049/jimmunol.169.9. 4882

Lee, S.-J., Myers, L., Muralimohan, G., Dai, J., Qiao, Y., Li, Z., et al. (2004). 4$1 \mathrm{BB}$ and $\mathrm{OX} 40$ dual costimulation synergistically stimulate primary specific CD8 T cells for robust effector function. J. Immunol. 173, 3002-3012. doi: 10.4049/jimmunol.173.5.3002

Lee, S.-W., Park, Y., Song, A., Cheroutre, H., Kwon, B. S., and Croft, M. (2006). Functional dichotomy between OX40 and 4-1BB in modulating effector CD8 T cell responses. J. Immunol. 177, 4464-4472. doi: 10.4049/jimmunol.177.7.4464

Lin, W., Voskens, C. J., Zhang, X., Schindler, D. G., Wood, A., Burch, E., et al. (2008). Fc-dependent expression of CD137 on human NK cells: insights into "agonistic" effects of anti-CD137 monoclonal antibodies. Blood 112, 699-707. doi: 10.1182/blood-2007-11-122465

Linch, S. N., Kasiewicz, M. J., McNamara, M. J., Hilgart-Martiszus, I. F., Farhad, M., and Redmond, W. L. (2016). Combination OX40 agonism/CTLA-4 blockade with HER2 vaccination reverses T-cell anergy and promotes survival in tumorbearing mice. Proc. Natl. Acad. Sci. U.S.A. 113, E319-E327.

Linton, P.-J., Bautista, B., Biederman, E., Bradley, E. S., Harbertson, J., Kondrack, R. M., et al. (2003). Costimulation via OX40L expressed by B cells is sufficient to determine the extent of primary CD4 cell expansion and Th2 cytokine secretion in vivo. J. Exp. Med. 197, 875-883. doi: 10.1084/jem.20021290

Lippert, U., Zachmann, K., Ferrari, D. M., Schwarz, H., Brunner, E., MahbubUl Latif, A. H. M., et al. (2008). CD137 ligand reverse signaling has multiple functions in human dendritic cells during an adaptive immune response. Eur. J. Immunol. 38, 1024-1032. doi: 10.1002/eji.200737800

Liu, Z., Kim, J. H., Falo, L. D. Jr., and You, Z. (2009). Tumor regulatory T cells potently abrogate antitumor immunity. J. Immunol. 182, 6160-6167. doi: 10. 4049/jimmunol.0802664

Lubrano di Ricco, M., Ronin, E., Collares, D., Divoux, J., Grégoire, S., Wajant, H., et al. (2020). Tumor necrosis factor receptor family costimulation increases regulatory T-cell activation and function via NF-кB. Eur. J. Immunol. 50, 972-985. doi: 10.1002/eji.201948393

Maimaitiyiming, Y., Hong, D., Yang, C., and Naranmandura, H. (2019). Novel insights into the role of aptamers in the fight against cancer. J. Cancer Res. Clin. Oncol. 145, 797-810. doi: 10.1007/s00432-019-02882-7

Makkouk, A., Chester, C., and Kohrt, H. E. (2016). Rationale for anti-CD137 cancer immunotherapy. Eur. J. Cancer 54, 112-119. doi: 10.1016/j.ejca.2015.09.026

Mallett, S., Fossum, S., and Barclay, A. N. (1990). Characterization of the MRC OX40 antigen of activated CD4 positive T lymphocytes-a molecule related to nerve growth factor receptor. EMBO J. 9, 1063-1068. doi: 10.1002/j.1460-2075. 1990.tb08211.x

Manrique-Rincón, A. J., Beraldo, C. M., Toscaro, J. M., and Bajgelman, M. C. (2017). Exploring synergy in combinations of tumor-derived vaccines that harbor 4-1BBL, OX40L, and GM-CSF. Front. Immunol. 8:1150. doi: 10.3389/ fimmu.2017.01150
Martinez-Forero, I., Azpilikueta, A., Bolaños-Mateo, E., Nistal-Villan, E., Palazon, A., Teijeira, A., et al. (2013). T cell costimulation with anti-CD137 monoclonal antibodies is mediated by K63-polyubiquitin-dependent signals from endosomes. J. Immunol. 190, 6694-6706. doi: 10.4049/jimmunol.1203010

Massarelli, E., Lam, V. K., Parra, E. R., Rodriguez-Canales, J., Behrens, C., Diao, L., et al. (2019). High OX-40 expression in the tumor immune infiltrate is a favorable prognostic factor of overall survival in non-small cell lung cancer. J. Immunother. Cancer 7:351.

Maxwell, J. R., Weinberg, A., Prell, R. A., and Vella, A. T. (2000). Danger and OX40 receptor signaling synergize to enhance memory $\mathrm{T}$ cell survival by inhibiting peripheral deletion. J. Immunol. 164, 107-112. doi: 10.4049/jimmunol.164.1. 107

McNamara, J. O., Kolonias, D., Pastor, F., Mittler, R. S., Chen, L., Giangrande, P. H., et al. (2008). Multivalent 4-1BB binding aptamers costimulate CD8+ $\mathrm{T}$ cells and inhibit tumor growth in mice. J. Clin. Invest. 118, 376-386. doi: $10.1172 /$ jci33365

Melero, I., Hirschhorn-Cymerman, D., Morales-Kastresana, A., Sanmamed, M. F., and Wolchok, J. D. (2013). Agonist antibodies to TNFR molecules that costimulate T and NK cells. Clin. Cancer Res. 19, 1044-1053. doi: 10.1158/10780432.ccr-12-2065

Melero, I., Johnston, J. V., Shufford, W. W., Mittler, R. S., and Chen, L. (1998). NK1.1 cells express 4-1BB (CDw137) costimulatory molecule and are required for tumor immunity elicited by anti-4-1BB monoclonal antibodies. Cell. Immunol. 190, 167-172. doi: 10.1006/cimm.1998.1396

Menk, A. V., Scharping, N. E., Rivadeneira, D. B., Calderon, M. J., Watson, M. J., Dunstane, D., et al. (2018). 4-1BB costimulation induces T cell mitochondrial function and biogenesis enabling cancer immunotherapeutic responses. J. Exp. Med. 215, 1091-1100. doi: 10.1084/jem.20171068

Miller, G. A., and Chapman, J. P. (2001). Misunderstanding analysis of covariance. J. Abnorm. Psychol. 110, 40-48. doi: 10.1037/0021-843x.110.1.40

Misumi, T., Tanabe, K., Fujikuni, N., and Ohdan, H. (2018). Stimulation of natural killer cells with rhCD137 ligand enhances tumor-targeting antibody efficacy in gastric cancer. PLoS One 13:e0204880. doi: 10.1371/journal.pone. 0204880

Morita, Y., Leslie, M., Kameyama, H., Volk, D. E., and Tanaka, T. (2018). Aptamer therapeutics in cancer: current and future. Cancers 10:80. doi: 10.3390/ cancers 10030080

Munks, M. W., Mourich, D. V., Mittler, R. S., Weinberg, A. D., and Hill, A. B. (2004). 4-1BB and OX40 stimulation enhance CD8 and CD4 T-cell responses to a DNA prime, poxvirus boost vaccine. Immunology 112, 559-566. doi: 10.1111/j.1365-2567.2004.01917.x

Ng, E. W. M., Shima, D. T., Calias, P., Cunningham, E. T., Guyer, D. R., and Adamis, A. P. (2006). Pegaptanib, a targeted anti-VEGF aptamer for ocular vascular disease. Nat. Rev. Drug Discov. 5, 123-132. doi: 10.1038/nrd1955

Niu, L., Strahotin, S., Hewes, B., Zhang, B., Zhang, Y., Archer, D., et al. (2007). Cytokine-mediated disruption of lymphocyte trafficking, hemopoiesis, and induction of lymphopenia, anemia, and thrombocytopenia in anti-CD137treated mice. J. Immunol. 178, 4194-4213. doi: 10.4049/jimmunol.178.7. 4194

Pastor, F., Berraondo, P., Etxeberria, I., Frederick, J., Sahin, U., Gilboa, E., et al. (2018). An RNA toolbox for cancer immunotherapy. Nat. Rev. Drug Discov. 17, 751-767. doi: 10.1038/nrd.2018.132

Pastor, F., Kolonias, D., McNamara, J. O. II, and Gilboa, E. (2011). Targeting 4-1BB costimulation to disseminated tumor lesions with bi-specific oligonucleotide aptamers. Mol. Ther. 19, 1878-1886. doi: 10.1038/mt.2011.145

Paterson, D. J., Jefferies, W. A., Green, J. R., Brandon, M. R., Corthesy, P., Puklavec, M., et al. (1987). Antigens of activated rat T lymphocytes including a molecule of 50,000 Mr detected only on CD4 positive T blasts. Mol. Immunol. 24, 1281-1290. doi: 10.1016/0161-5890(87)90122-2

Pattarini, L., Trichot, C., Bogiatzi, S., Grandclaudon, M., Meller, S., Keuylian, Z., et al. (2017). TSLP-activated dendritic cells induce human T follicular helper cell differentiation through OX40-ligand. J. Exp. Med. 214, 1529-1546. doi: 10.1084/jem.20150402

Peng, W., Williams, L. J., Xu, C., Melendez, B., McKenzie, J. A., Chen, Y., et al. (2019). Anti-OX40 antibody directly enhances the function of tumor-reactive CD8(+) T cells and synergizes with PI3K $\beta$ inhibition in PTEN loss melanoma. Clin. Cancer Res. 25, 6406-6416. doi: 10.1158/1078-0432.ccr-19-1259 
Piconese, S., Valzasina, B., and Colombo, M. P. (2008). OX40 triggering blocks suppression by regulatory $\mathrm{T}$ cells and facilitates tumor rejection. J. Exp. Med. 205, 825-839. doi: 10.1084/jem.20071341

Pollok, K. E., Kim, S. H., and Kwon, B. S. (1995). Regulation of 4-1BB expression by cell-cell interactions and the cytokines, interleukin-2 and interleukin-4. Eur. J. Immunol. 25, 488-494. doi: 10.1002/eji.1830250227

Pollok, K. E., Kim, Y. J., Hurtado, J., Zhou, Z., Kim, K. K., and Kwon, B. S. (1994). 4-1BB T-cell antigen binds to mature B cells and macrophages, and costimulates anti-mu-primed splenic B cells. Eur. J. Immunol. 24, 367-374. doi: 10.1002/eji.1830240215

Pollok, K. E., Kim, Y. J., Zhou, Z., Hurtado, J., Kim, K. K., Pickard, R. T., et al. (1993). Inducible T cell antigen 4-1BB. analysis of expression and function. J. Immunol. 150, 771-781.

Porter, D. L., Levine, B. L., Kalos, M., Bagg, A., and June, C. H. (2011). Chimeric antigen receptor-modified T cells in chronic lymphoid leukemia. N. Engl. J. Med. 365, 725-733. doi: 10.1056/nejmoa1 103849

Pratico, E. D., Sullenger, B. A., and Nair, S. K. (2013). Identification and characterization of an agonistic aptamer against the $\mathrm{T}$ cell costimulatory receptor, OX40. Nucleic Acid Ther. 23, 35-43. doi: 10.1089/nat.2012.0388

Qi, X., Li, F., Wu, Y., Cheng, C., Han, P., Wang, J., et al. (2019). Optimization of 4$1 \mathrm{BB}$ antibody for cancer immunotherapy by balancing agonistic strength with Fc $\gamma$ R affinity. Nat. Commun. 10:2141.

Rajagopalan, A., Berezhnoy, A., Schrand, B., Puplampu-Dove, Y., and Gilboa, E. (2017). Aptamer-targeted attenuation of IL-2 signaling in CD8(+) T cells enhances antitumor immunity. Mol. Ther. 25, 54-61. doi: 10.1016/j.ymthe. 2016.10.021

Rajasekaran, N., Chester, C., Yonezawa, A., Zhao, X., and Kohrt, H. E. (2015). Enhancement of antibody-dependent cell mediated cytotoxicity: a new era in cancer treatment. Immunotargets Ther. 4, 91-100. doi: 10.2147/itt.s61292

Redmond, W. L., Ruby, C. E., and Weinberg, A. D. (2009). The role of OX40mediated co-stimulation in T-cell activation and survival. Crit. Rev. Immunol. 29, 187-201. doi: 10.1615/critrevimmunol.v29.i3.10

Rogers, P. R., Song, J., Gramaglia, I., Killeen, N., and Croft, M. (2001). OX40 promotes Bcl-xL and Bcl-2 expression and is essential for long-term survival of CD4 T cells. Immunity 15, 445-455. doi: 10.1016/s1074-7613(01)00191-1

Rothe, M., Sarma, V., Dixit, V. M., and Goeddel, D. V. (1995). TRAF2-mediated activation of NF-kappa B by TNF receptor 2 and CD40. Science 269, 1424-1427. doi: 10.1126/science.7544915

Sabbagh, L., Pulle, G., Liu, Y., Tsitsikov, E. N., and Watts, T. H. (2008). ERKdependent Bim modulation downstream of the 4-1BB-TRAF1 signaling axis is a critical mediator of CD8 T cell survival in vivo. J. Immunol. 180, 8093-8101. doi: 10.4049/jimmunol.180.12.8093

Sadler, R., Bateman, E. A. L., Heath, V., Patel, S. Y., Schwingshackl, P. P., Cullinane, A. C., et al. (2014). Establishment of a healthy human range for the whole blood "OX40" assay for the detection of antigen-specific CD4+ T cells by flow cytometry. Cytometry B Clin. Cytom. 86, 350-361.

Salek-Ardakani, S., Song, J., Halteman, B. S., Jember, A. G.-H., Akiba, H., Yagita, H., et al. (2003). OX40 (CD134) controls memory $\mathrm{T}$ helper 2 cells that drive lung inflammation. J. Exp. Med. 198, 315-324. doi: 10.1084/jem.200 21937

Salih, H. R., Kosowski, S. G., Haluska, V. F., Starling, G. C., Loo, D. T., Lee, F., et al. (2000). Constitutive expression of functional 4-1BB (CD137) ligand on carcinoma cells. J. Immunol. 165, 2903-2910. doi: 10.4049/jimmunol.165.5. 2903

Santulli-Marotto, S., Nair, S. K., Rusconi, C., Sullenger, B., and Gilboa, E. (2003). Multivalent RNA aptamers that inhibit CTLA-4 and enhance tumor immunity. Cancer Res. 63, 7483-7489.

Saoulli, K., Lee, S. Y., Cannons, J. L., Yeh, W. C., Santana, A., Goldstein, M. D., et al. (1998). CD28-independent, TRAF2-dependent costimulation of resting T cells by 4-1BB ligand. J. Exp. Med. 187, 1849-1862. doi: 10.1084/jem.187.11.1849

Schabowsky, R.-H., Elpek, K. G., Madireddi, S., Sharma, R. K., Yolcu, E. S., Bandura-Morgan, L., et al. (2009). A novel form of 4-1BBL has better immunomodulatory activity than an agonistic anti-4-1BB $\mathrm{Ab}$ without $\mathrm{Ab}$ associated severe toxicity. Vaccine 28, 512-522. doi: 10.1016/j.vaccine.2009.09. 127

Schoenbrunn, A., Frentsch, M., Kohler, S., Keye, J., Dooms, H., Moewes, B., et al. (2012). A converse 4-1BB and CD40 ligand expression pattern delineates activated regulatory $\mathrm{T}$ cells (Treg) and conventional $\mathrm{T}$ cells enabling direct isolation of alloantigen-reactive natural Foxp3+ Treg. J. Immunol. 189, 59855994. doi: 10.4049/jimmunol.1201090

Schrand, B., Berezhnoy, A., Brenneman, R., Williams, A., Levay, A., and Gilboa, E. (2015). Reducing toxicity of 4-1BB costimulation: targeting 4-1BB ligands to the tumor stroma with bi-specific aptamer conjugates. Oncoimmunology 4:e970918. doi: 10.4161/21624011.2014.970918

Schrand, B., Berezhnoy, A., Brenneman, R., Williams, A., Levay, A., Kong, L.-Y., et al. (2014). Targeting 4-1BB costimulation to the tumor stroma with bispecific aptamer conjugates enhances the therapeutic index of tumor immunotherapy. Cancer Immunol. Res. 2, 867-877. doi: 10.1158/2326-6066.cir14-0007

Schwarz, H., Tuckwell, J., and Lotz, M. (1993). A receptor induced by lymphocyte activation (ILA): a new member of the human nerve-growth-factor/tumornecrosis-factor receptor family. Gene 134, 295-298. doi: 10.1016/03781119(93)90110-o

Segal, N. H., Gopal, A. K., Bhatia, S., Kohrt, H. E., Levy, R., Pishvaian, M. J., et al. (2014). A phase 1 study of PF-05082566 (anti-4-1BB) in patients with advanced cancer. J. Clin. Oncol. 32(15_Suppl.):3007. doi: 10.1200/jco.2014.32.15_suppl. 3007

Semionatto, I. F., Palameta, S., Toscaro, J. M., Manrique-Rincón, A. J., Ruas, L. P., Paes Leme, A. F., et al. (2020). Extracellular vesicles produced by immunomodulatory cells harboring OX40 ligand and 4-1BB ligand enhance antitumor immunity. Sci. Rep. 10:15160.

Sharma, R. K., Srivastava, A. K., Yolcu, E. S., MacLeod, K. J., Schabowsky, R.-H., Madireddi, S., et al. (2010). SA-4-1BBL as the immunomodulatory component of a HPV-16 E7 protein based vaccine shows robust therapeutic efficacy in a mouse cervical cancer model. Vaccine 28, 5794-5802. doi: 10.1016/j.vaccine. 2010.06.073

Shi, W., and Siemann, D. W. (2006). Augmented antitumor effects of radiation therapy by $4-1 \mathrm{BB}$ antibody (BMS-469492) treatment. Anticancer Res. 26, 34453453.

Shuford, W. W., Klussman, K., Tritchler, D. D., Loo, D. T., Chalupny, J., Siadak, A. W., et al. (1997). 4-1BB costimulatory signals preferentially induce CD8+ $\mathrm{T}$ cell proliferation and lead to the amplification in vivo of cytotoxic $\mathrm{T}$ cell responses. J. Exp. Med. 186, 47-55. doi: 10.1084/jem.186.1.47

So, T., and Croft, M. (2007). Cutting edge: OX40 inhibits TGF-beta- and antigendriven conversion of naive CD4 T cells into CD25+Foxp3+ T cells. J. Immunol. 179, 1427-1430. doi: 10.4049/jimmunol.179.3.1427

Song, J., Salek-Ardakani, S., Rogers, P. R., Cheng, M., Van Parijs, L., and Croft, M. (2004). The costimulation-regulated duration of $\mathrm{PKB}$ activation controls $\mathrm{T}$ cell longevity. Nat. Immunol. 5, 150-158. doi: 10.1038/ni1030

Song, J., So, T., and Croft, M. (2008). Activation of NF-kappaB1 by OX40 contributes to antigen-driven T cell expansion and survival. J. Immunol. 180, 7240-7248. doi: 10.4049/jimmunol.180.11.7240

Steurer, M., Montillo, M., Scarfò, L., Mauro, F. R., Andel, J., Wildner, S., et al. (2019). Olaptesed pegol (NOX-A12) with bendamustine and rituximab: a phase IIa study in patients with relapsed/refractory chronic lymphocytic leukemia. Haematologica 104, 2053-2060. doi: 10.3324/haematol.2018.205930

Swart, M., Verbrugge, I., and Beltman, J. B. (2016). Combination approaches with immune-checkpoint blockade in cancer therapy. Front. Oncol. 6:233. doi: 10.3389/fonc. 2016.00233

Tahiliani, V., Hutchinson, T. E., Abboud, G., Croft, M., and Salek-Ardakani, S. (2017). OX40 Cooperates with ICOS To amplify follicular Th cell development and germinal center reactions during infection. J. Immunol. 198, 218-228. doi: 10.4049/jimmunol.1601356

Takahashi, C., Mittler, R. S., and Vella, A. T. (1999). Cutting edge: 4-1BB is a bona fide CD8 T cell survival signal. J. Immunol. 162, 5037-5040.

Tan, J. T., Ha, J., Cho, H. R., Tucker-Burden, C., Hendrix, R. C., Mittler, R. S., et al. (2000). Analysis of expression and function of the costimulatory molecule 4-1BB in alloimmune responses. Transplantation 70, 175-183.

Tolcher, A. W., Sznol, M., Hu-Lieskovan, S., Papadopoulos, K. P., Patnaik, A., Rasco, D. W., et al. (2017). Phase Ib study of utomilumab (PF-05082566), a $4-1 \mathrm{BB} / \mathrm{CD} 137$ agonist, in combination with pembrolizumab (MK-3475) in patients with advanced solid tumors. Clin. Cancer Res. 23, 5349-5357. doi: 10.1158/1078-0432.ccr-17-1243

Tuerk, C., and Gold, L. (1990). Systematic evolution of ligands by exponential enrichment: RNA ligands to bacteriophage T4 DNA polymerase. Science 249, 505-510. doi: $10.1126 /$ science. 2200121 
Valzasina, B., Guiducci, C., Dislich, H., Killeen, N., Weinberg, A. D., and Colombo, M. P. (2005). Triggering of OX40 (CD134) on CD4+CD25+ T cells blocks their inhibitory activity: a novel regulatory role for OX40 and its comparison with GITR. Blood 105, 2845-2851. doi: 10.1182/blood-2004-07-2959

van der Stegen, S. J. C., Hamieh, M., and Sadelain, M. (2015). The pharmacology of second-generation chimeric antigen receptors. Nat. Rev. Drug Discov. 14, 499-509. doi: 10.1038/nrd4597

Vinay, D. S., and Kwon, B. S. (2014). 4-1BB (CD137), an inducible costimulatory receptor, as a specific target for cancer therapy. BMB Rep. 47, 122-129. doi: 10.5483/bmbrep.2014.47.3.283

Vu, M. D., Xiao, X., Gao, W., Degauque, N., Chen, M., Kroemer, A., et al. (2007). OX40 costimulation turns off Foxp3 + Tregs. Blood 110, 2501-2510. doi: 10.1182/blood-2007-01-070748

Walker, L. S., Gulbranson-Judge, A., Flynn, S., Brocker, T., Raykundalia, C., Goodall, M., et al. (1999). Compromised OX40 function in CD28-deficient mice is linked with failure to develop CXC chemokine receptor 5-positive CD4 cells and germinal centers. J. Exp. Med. 190, 1115-1122. doi: 10.1084/jem.190.8.1115

Weinberg, A. D., Rivera, M. M., Prell, R., Morris, A., Ramstad, T., Vetto, J. T., et al. (2000). Engagement of the OX-40 receptor in vivo enhances antitumor immunity. J. Immunol. 164, 2160-2169. doi: 10.4049/jimmunol.164.4.2160

Weinberg, A. D., Wegmann, K. W., Funatake, C., and Whitham, R. H. (1999). Blocking OX-40/OX-40 ligand interaction in vitro and in vivo leads to decreased $\mathrm{T}$ cell function and amelioration of experimental allergic encephalomyelitis. J. Immunol. 162, 1818-1826.

Wen, T., Bukczynski, J., and Watts, T. H. (2002). 4-1BB ligand-mediated costimulation of human $\mathrm{T}$ cells induces CD4 and CD8 T cell expansion, cytokine production, and the development of cytolytic effector function. J. Immunol. 168, 4897-4906. doi: 10.4049/jimmunol.168.10.4897

Wilcox, R. A., Chapoval, A. I., Gorski, K. S., Otsuji, M., Shin, T., Flies, D. B., et al. (2002). Cutting edge: expression of functional CD137 receptor by dendritic cells. J. Immunol. 168, 4262-4267. doi: 10.4049/jimmunol.168.9. 4262

Xiao, Y., Hendriks, J., Langerak, P., Jacobs, H., and Borst, J. (2004). CD27 is acquired by primed $\mathrm{B}$ cells at the centroblast stage and promotes germinal center formation. J. Immunol. 172, 7432-7441. doi: 10.4049/jimmunol.172.12. 7432

Xu, L., Xu, W., Qiu, S., and Xiong, S. (2010). Enrichment of CCR6+Foxp3+ regulatory $\mathrm{T}$ cells in the tumor mass correlates with impaired $\mathrm{CD} 8+\mathrm{T}$ cell function and poor prognosis of breast cancer. Clin. Immunol. 135, 466-475. doi: 10.1016/j.clim.2010.01.014

Xu, L.-G., Li, L.-Y., and Shu, H.-B. (2004). TRAF7 potentiates MEKK3-induced AP1 and CHOP activation and induces apoptosis. J. Biol. Chem. 279, 1727817282. doi: 10.1074/jbc.c400063200

Youlin, K., Li, Z., Xin, G., Mingchao, X., Xiuheng, L., and Xiaodong, W. (2013). Enhanced function of cytotoxic $\mathrm{T}$ lymphocytes induced by dendritic cells modified with truncated PSMA and 4-1BBL. Hum. Vaccin. Immunother. 9, 766-772. doi: 10.4161/hv.23116

Zaini, J., Andarini, S., Tahara, M., Saijo, Y., Ishii, N., Kawakami, K., et al. (2007). OX40 ligand expressed by DCs costimulates NKT and CD4+ Th cell antitumor immunity in mice. J. Clin. Invest. 117, 3330-3338. doi: 10.1172/jci32693

Zboralski, D., Hoehlig, K., Eulberg, D., Frömming, A., and Vater, A. (2017). Increasing tumor-infiltrating T cells through inhibition of CXCL12 with NOXA12 synergizes with PD-1 blockade. Cancer Immunol. Res. 5, 950-956. doi: 10.1158/2326-6066.cir-16-0303

Zhang, P., Gao, F., Wang, Q., Wang, X., Zhu, F., Ma, C., et al. (2007). Agonistic anti-4-1BB antibody promotes the expansion of natural regulatory $\mathrm{T}$ cells while maintaining Foxp3 expression. Scand. J. Immunol. 66, 435-440. doi: 10.1111/j. 1365-3083.2007.01994.x

Zhang, X., Voskens, C. J., Sallin, M., Maniar, A., Montes, C. L., Zhang, Y., et al. (2010). CD137 promotes proliferation and survival of human B cells. J. Immunol. 184, 787-795. doi: 10.4049/jimmunol.0901619

Zhou, Z., Kim, S., Hurtado, J., Lee, Z. H., Kim, K. K., Pollok, K. E., et al. (1995). Characterization of human homologue of 4-1BB and its ligand. Immunol. Lett. 45, 67-73. doi: 10.1016/0165-2478(94)00227-i

Conflict of Interest: The authors declare that the research was conducted in the absence of any commercial or financial relationships that could be construed as a potential conflict of interest.

Copyright (C) 2021 Mascarelli, Rosa, Toscaro, Semionatto, Ruas, Fogagnolo, Lima and Bajgelman. This is an open-access article distributed under the terms of the Creative Commons Attribution License (CC BY). The use, distribution or reproduction in other forums is permitted, provided the original author(s) and the copyright owner(s) are credited and that the original publication in this journal is cited, in accordance with accepted academic practice. No use, distribution or reproduction is permitted which does not comply with these terms. 